\title{
Special Thematic Section "Eisenstein, Bogdanov, and the Organization of Culture": Guest Editorial Introduction
}

This special thematic section of Cultural Science Journal is devoted to the cultural theories and practice of two individuals who exerted great influence on early Soviet intellectual life, Sergei M. Eisenstein (1898-1948) and Aleksandr A. Bogdanov (1873-1928). Most of the papers in this issue were delivered to an international arts and science conference, 'Tangential Points', held at the Aalto University School of Arts, Design and Architecture in 2014, and were in their initial form published in an experimental online platform 'Spherical Book' (2016-17). The papers have been updated and peer-reviewed anew. Translations of little-known texts by Eisenstein and Bogdanov were a feature of the original publication; these have been included.

The Tangential Points conference was convened to reflect upon apparent similarities between the systemic thinking of Eisenstein and Bogdanov, as hypothesized in Enactive Cinema: Simulatorium Eisensteinense (Tikka 2008). The principal inspiration for the conference, however, came from the work of the Finnish scholar IImari Susiluoto, notably The Origins and Development of Systems Thinking in the Soviet Union (1982). This volume is dedicated to the memory of IImari Susiluoto (1947-2016).

\section{Bogdanov and Eisenstein}

We do not know whether Bogdanov and Eisenstein ever met, but during the early years of the Soviet régime their ideas found expression in the Russian Proletarian Cultural-Educational Organization, the Proletkult. This was an extra-curricular institution that sought to create a new 'proletarian culture' by fostering the values of collectivism through tuition in philosophy, literature, theatre, the graphic arts and the sciences. After the October Revolution, institutions based on the Proletkult sprang up in a number of Western European countries.

An economist, culturologist, science fiction writer and experimental haematologist, Bogdanov was the principal theorist of the Proletkult (1917-32). In what he considered to be his key work, Tektology: Universal Organizational Science (1913-22), based on the natural sciences rather than Hegelian dialectics, he identified what he considered to be the common mechanisms that determined the evolution and inter-relationship of nature, society, and the mind. Central to Bogdanov's conception of 'cultural revolution' was the hope that his universal organizational science would serve as an analytical and practical instrument for the working class in its struggle for socialism. One of Lenin's closest collaborators between 1904 and 1909, Bogdanov thereafter became his most feared intellectual rival. Shortly after Bogdanov's death in 1928, his works ceased to be published. However, although he had been denounced as a 'heretic' as early as 1920, his ideas were a latent influence in the development of Soviet economic and cultural thought. In the late 1960s and early 1970 s he was rehabilitated and his ideas have attracted increasing interest.

The career of Sergei M. Eisenstein was very different. During his life, and to an even greater degree after his death, he had an enormous impact not only on Soviet film culture but on film culture throughout 
the world. The Proletkult, which sought to educate the proletarian masses in the values of collectivism, was an important post-revolutionary framework for the young film director and theoretician.

Guest Editorial Board: Pia Tikka (Editor-in-Chief), John Biggart, Vesa Oittinen, Simona Poustilnik, Giulia Rispoli, Maja Soboleva

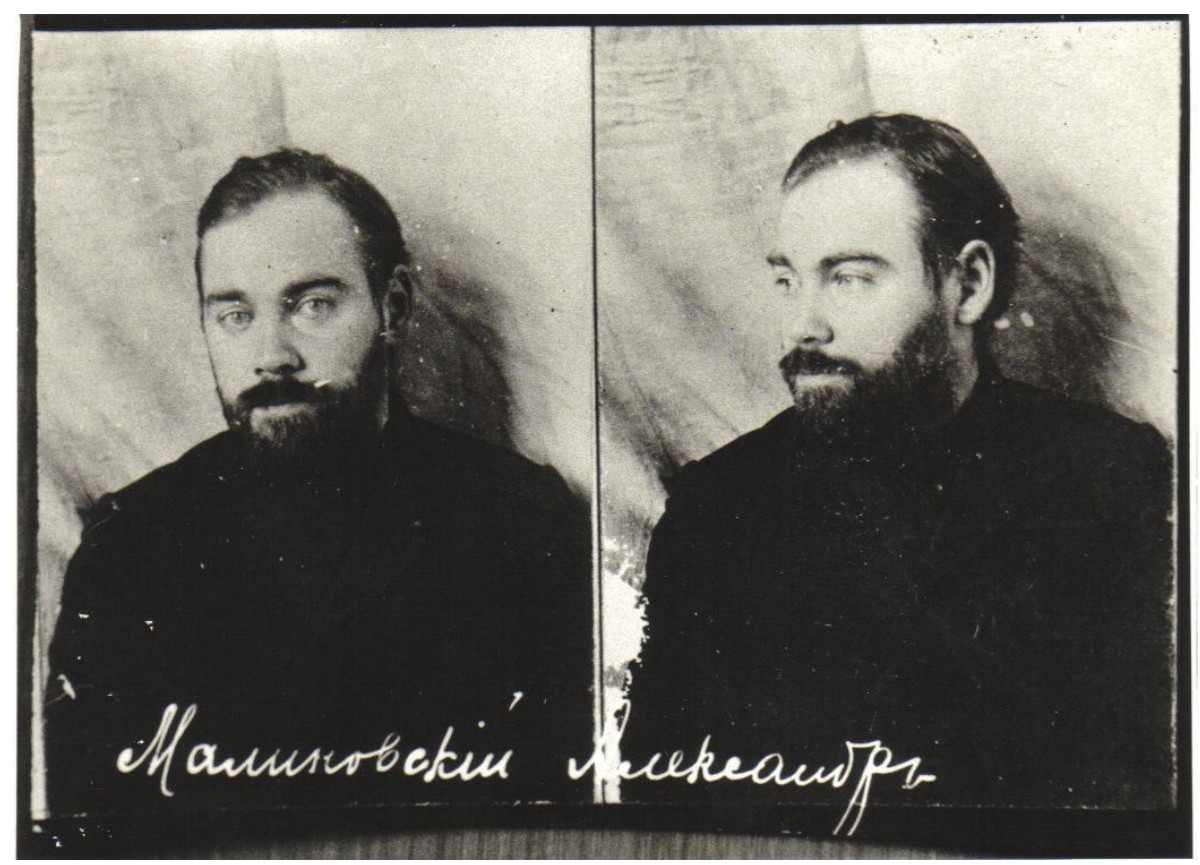

AA. Bogdanov in about 1905-1906, police photo. Courtesy of Simona Poustilnik. Photograph discovered by Simona Poustilnik in the State Archive of the Russian Federation (GARF)

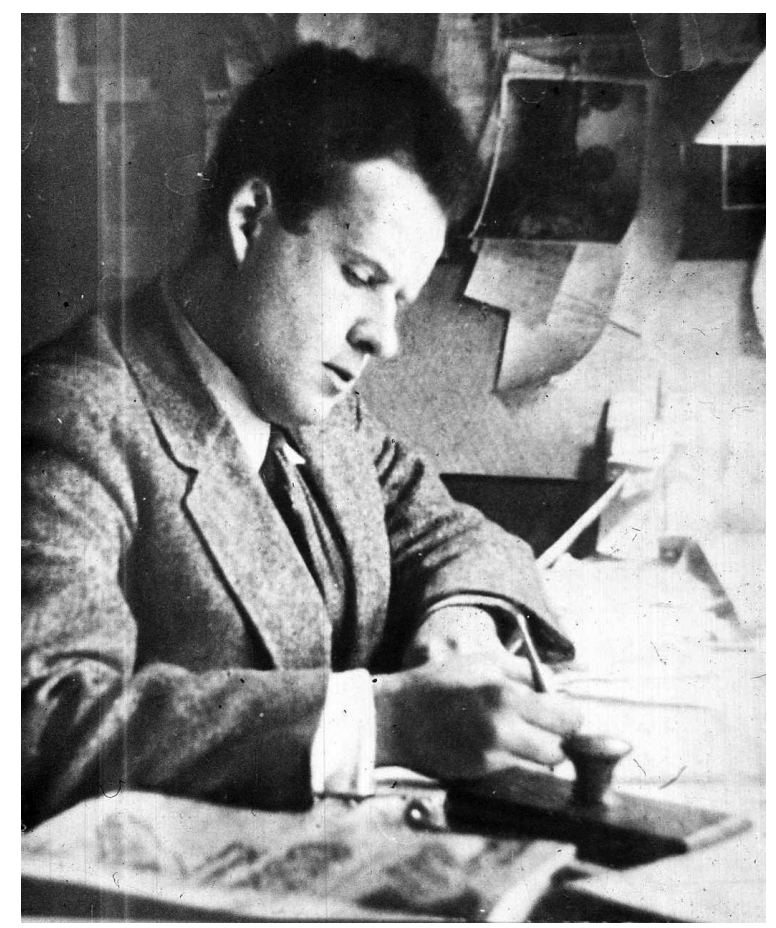




\section{Content of the special theme section}

1. Pia Tikka / commentary: Steve Anderson / commentary: Nadejda Grigorieva TANGENTIAL POINTS: ALEKSANDR BOGDANOV AND SERGEI EISENSTEIN REVISITED

2. John Biggart \& Oksana Bulgakowa / commentary: lan Christie SERGEI EISENSTEIN IN THE PROLETKULT

3. Oksana Bulgakowa / commentary: Pietro Montani SERGEI EISENSTEIN'S SYSTEM THINKING: INFLUENCES AND INSPIRATIONS

4. Lyuba Bugaeva / commentary: Sergey Ogudov ALEKSANDR BOGDANOV AND SERGEI EISENSTEIN ON EMOTIONS: THE AFFECTIONAL, THE THEORY OF EXPRESSIVENESS, AND THE EMOTIONAL SCRIPT

5. Clea Waite / commentary: Szilvia Ruszev SOMATIC MONTAGE FOR IMMERSIVE CINEMA

6. Giulia Rispoli / commentary: Arran Gare SHARING IN ACTION: THE SYSTEMIC CONCEPT OF THE ENVIRONMENT IN ALEKSANDR BOGDANOV

7. Simona Poustilnik / commentary: Carlo Rovelli ALEKSANDR BOGDANOV'S TEKTOLOGY: A PROLETARIAN SCIENCE OF CONSTRUCTION

8. Peter Dudley / commentary: Örsan Şenalp ALEKSANDR BOGDANOV'S PODBOR AND PROLETKULT: AN ADAPTIVE SYSTEMS PERSPECTIVE

9. Fabian Tompsett / commentary: Redas Dirzys TOWARDS A TEKTOLOGY OF TEKTOLOGY

10. Vesa Oittinen / commentary: Antti Hautamäki / commentary: Pietro Omodeo ALEKSANDR BOGDANOV AND LENIN ON 'THINGS-IN-THEMSELVES'

11. Jutta Scherrer / commentary: David Rowley ALEKSANDR BOGDANOV'S CONCEPT OF CULTURE: FROM WORKERS' CIRCLES TO THE PROLETKULT MOVEMENT

12. Maja Soboleva / commentary; Frances Nethercott THE CULTURE AS SYSTEM, THE SYSTEM OF CULTURE. ALEKSANDR BOGDANOV ON PROLETARIAN CULTURE AND PROLETARIAN ART

13. Daniel Steila / commentary: Evgeni V. Pavlov KNOWLEDGE AS FILM VS. KNOWLEDGE AS PHOTO: ALTERNATIVE MODELS IN EARLY SOVIETTHOUGHT

14. John Biggart / commentary: Christopher J.Read ALEKSANDR BOGDANOV'S SOCIOLOGY OF THE ARTS

\section{Documents}

15. Franz Seiwert, 'AN OPEN LETTER TO COMRADE BOGDANOV' (1921), translation and introduction Fabian Tompsett

16. Sergei Eisenstein, 'CINEMA OF THE MASSES' (1925), translation Richard Abraham, introduction Oksana Bulgakowa and John Biggart

17. Sergei Eisenstein, 'THE MAGIC OF ART' (1947), translation and introduction Julia Vassilieva

18. Aleksandr Bogdanov 'SCIENCE AND THE WORKING CLASS', translation and introduction Fabian Tompsett 


\section{Contributors \\ (Listed alphabetically)}

Abraham, Richard - Anderson, Steven F. - Biggart, John - Bulgakowa, Oksana - Bugaeva, Lyubov Chamier-Waite, Clea von - Christie, lan - Diržys, Redas - Dudley, Peter - Gare, Arran - Grigoryeva, Nadezda - Hautamäki, Antti - Montani, Pietro - Nethercott, Frances - Ogudov, Sergey - Omodeo, Pietro D. - Oittinen, Vesa - Pavlov, Evgeni V. - Poustilnik, Simona - Read, Christopher - Rispoli, Giulia Rovelli, Carlo - Rowley, David - Ruszev, Szilvia - Scherrer, Jutta - Şenalp, Örsan - Soboleva, Maja Steila, Daniela - Tikka, Pia - Tompsett, Fabian - Vassilieva, Julia 